\title{
Economic Principles of Mining Region Sustainable Development
}

\author{
Sergey Zhironkin ${ }^{1, *}$, Dmitriy Khloptsov ${ }^{2}$, Natalya Skrylnikova $^{2}$, Irina Petinenko ${ }^{2}$, and Olga \\ Zhironkina $^{3}$ \\ ${ }^{1}$ T.F. Gorbachev Kuzbass State Technical University, 650000 Kemerovo, 28 Vesennya st., \\ Kemerovo, Russia \\ ${ }^{2}$ National Research Tomsk State University, 634050, 36 Lenina ave, Tomsk, Russia \\ ${ }^{3}$ Plekhanov Russian University of Economics, Kemerovo branch, 650992, pr. Kuznetskiy, 39, \\ Kemerovo, Russia
}

\begin{abstract}
The concept of sustainable development in comparison with other paradigms was the most acceptable, from the point of view of determining the development strategy of society, in the medium and long term. Due to that, such important trends in science and practice as the restructuring and modernization of the economy, energy efficiency, environmental security, "green economy", etc. have been developed. One of the most important areas of research, important both for science and practice, is the measurement sustainability of development using the system of indicators. The quantitative measurement of sustainability makes it possible to shape strategies for the development of countries and regions, taking into account the ecological, social factors that previously could not even compete with economic factors. For Russia, this is important from different perspectives. Among the main reasons there is a significant differentiation of regions in terms of development level and the predominance of "raw materials" in the structure of the economy of many regions. Rational use of natural resources is a necessary condition for the sustainable development of any state or region.
\end{abstract}

\section{Introduction}

To date, the problem of choosing development priorities is of particular importance, which is due to the qualitative changes taking place in the world economy. The importance of this problem was noted in the decisions of the United Nations conferences on environment and development (Rio de Janeiro, 1992) and (Johannesburg, 2002), which offer an alternative to social-and-economic growth - the concept of "sustainable development" characterized by the single approach to the evolution of each aspect: economic, social and environmental.

The human society, like any other complex self-organized system, is simultaneously a system of dynamic, i.e. it is continuously transforming and changing. The changes that occur in it affect the existing social, economic and political relations. The stability of the dynamic system, in accordance with modern development theories, is determined by the simultaneous influence of two polar tendencies - "negative", associated with the

\footnotetext{
* Corresponding author: zhironkin@inbox.ru
} 
reproduction and preservation of the "old" system qualities, and "positive", providing the possibility of adaptation to "new" conditions, changes in the external environment. Such "dynamic stability" of development serves as an ideal model for different societies, which makes it possible to overcome effectively the development crises and solve social problems. This determines the popularity of the so-called concept of "sustainable development" among other theories of social change.

\section{Materials and Methods}

In this study, the authors focus on the environmental and economic aspects of sustainable development at the regional level. Here, in addition to systemic problems, the main ones being the continuing pollution of environment in the course of economic and domestic activities and low effectiveness of environmental protection measures, we can mention a lesser provision of financial and human resources [1-3].

In addition, a very significant aspect of environmental and economic sustainability under current conditions is the actual disconnection of production processes and environmental protection [4]. Therefore, along with the formation of a mechanism regulating social-and-economic development, in particular nature management and anthropogenic impact on the environment, it is advisable to envisage the reconstruction of a regional industrial system taking into account the economic capacity of local ecosystems. It is important to note the need to take into account both the social-and-economic and environmental interests of the local population in forecasting and planning the development of the region, the development of regional social-and-economic and environmental programs for sustainable development. Underestimation of the environmental factor and environmental constraints in the preparation of territorial development documents leads not only to many negative consequences in the use of natural resources, but also to deep longterm disparities between the economic, social and ecological development of systems at various levels, affecting the quality and effectiveness of environmental regulation mechanisms [5-6]. In this regard, the consideration of the environmental factor in regional practice of management of the territory's sustainable development becomes particularly important.

In 2017 it had been 25 years since the adoption of the Concept of Sustainable Development at a conference in Rio de Janeiro. From the point of view of the development of society this is an insignificant period, but for individual countries this is a whole era of institutional changes and the development of market relations. For Russia, this is the era of cardinal changes in all spheres of life and, especially, in political and economic.

Over the years, there have been significant changes in the regions, even in the context of the raw materials orientation of the economy. For the Kemerovo region the following changes of this period can be named:

- the development of a new institutional environment (legislation; new technologies, changing people's thinking; the appearing of signs of a new economic space);

- economic recovery based on the fuel and economic and metallurgical industries;

- appearing of signs of economic restructuring due to an increase in the share of nonproductive sectors (trade, communications, other services, etc.);

- appearing of signs of synchronization of the main, auxiliary and life-supporting processes of regional development;

- administrative reform and development of strategic plans of various levels, etc.

The provisions and principles of the concept of sustainable development have been a benchmark for all these years to identify positive trends in the development of regions and the country as a whole. In the Kemerovo region over the past five years, for the first time in many years, it has become possible to see stable positive trends in social-and-ecological 
and economic development recorded in official statistics. This is not only an increase in coal production and per capita GRP, but also a decrease in GRP energy intensity, stabilization of emissions, an improvement in the "quality of investments" and diversification of investment flows. The most important indicators for improving social and economic development can be called a reduction in the death rate of the population, and primarily of children, and an increase in life expectancy. In the Kemerovo region, in comparison with other regions of the fuel and energy complex, the most dynamically increases the index of human development. It is quite obvious that several years of improvement, especially in the conditions of the global financial crisis, do not allow making an unambiguous conclusion about the region's transition to the sustainable development, but show the importance of further progress in this direction and the need for careful monitoring of indicators of sustainable development that are important for decisionmaking on the strategy of regional development. The main problem of the region is the high environmental intensity of the economy.

\section{Results and Discussion}

We have identified a fairly wide range of principles that constitute the theoretical basis for approaches to the influence on the economy formed by various scientific economic schools. At the same time, proceeding from the need for establishing a neo-industrial form of structural transformations of the Russian economy, it is worthwhile to single out a number of principles that contribute to its fullest disclosure.

The first principle is a systemic, multilevel nature of purposeful neo-industrial transformations of the economy. This principle means a consistent analysis of the regulated changes in the structure of the economy during the innovative development of industry, both at the level of economic practice and at the level of economic relations. Their modification should affect not only economic relations in the system of state regulation of the economy, but also in the reproduction of industrial capital in the process of investing, lending, and vertical integration of enterprises; in changing the nature of labor, in the development of new institutions, models of economic behavior, social relations. Following this principle, the aggregate of the regulatory impact on the economy with the aim of moving along the neo-industrial path requires using in the complex normative, indicative and program-targeted regulations, as well as market self-regulation of innovative activity, investment process, industrial clustering, and entrepreneurship development.

The second principle is the priority of the neo-industrial attractor, which means reorienting the state structural policy from creating the most favorable conditions for the development of the oil and gas complex to the development of production of the 5th and 6th technological layers.

The third principle is the use of forms and instruments of regulated neo-industrial economic transformations in accordance with the depth of the problems of its structure. Taking into account the gap between Russia and developed countries in the technological level of production, in labor productivity, in the added value of the product being created, one can judge the absence of many modern institutions of economy and society, intersubject interactions, patterns of economic behavior in the national economy. And for their development it is necessary to regulate the innovative, investment, credit spheres both in direct and indirect ways.

The fourth principle is a consistent and reinforced by the demand for innovation transition from the export of raw materials to the export of processed products. In fact, this means using import substitution as the main economic condition for the neoindustrialization of the Russian economy, with the use of a neo-industrial state order, invasive state investments, and the development of public-private payment platforms. 
The fifth principle is the formation of the target social group as the key social-andeconomic condition for neo-industrialization, during which the role of intellectual rent, information technology, and high-tech services should inevitably grow in the Russian economy.

The sixth principle is strategic target programming as a guarantee of successful state participation in the implementation of neo-industrial structural transformations of the economy. Today, in many countries that actively implement neo-industrial transformation, national neo-industrial strategies have been formed and are being implemented: in the USA - Advanced Manufacturing Partnership (Select USA); in the EU - Agenda for European Manufacturing on a Changing World; in China - China Industry Challenge. Today, there is a great need for such a strategy in the Russian economy.

Thus, the principles of neo-industrially oriented economic transformations reflect the imperatives of the development of economic relations in the structure of the national economy, the driving forces of its adaptation to the acceleration of scientific and technological progress, the globalization of economic activity, and the changing role of the state in conditions of deep technological shifts. Such driving forces of neo-industrialization as the modification of capital and the changing nature of labor in the development of venture investment, the emergence of the innovation and intellectual capital market, and the development of property forms within the framework of public-private partnerships in the innovation sphere determine the set of conditions for neo-industrially oriented economic transformations [7].

Institutional conditions include the development of state and business institutions capable of initiating transformations, first of all, of the innovation-technological, reproductive, factorial, sectoral, social structure of the economy, creating a reserve for the transition to the fifth layer of technological development.

Reproductive conditions of neo-industrialization consist in accelerating the renewal of the fixed capital of branches of the 5-th layer by 2-2.5 times, in raising the rate of accumulation to $33-35 \%$ of GDP (today - no more than $20 \%$ ) in attracting investments in the 6 -th (today less than $0.5 \%$ ), in reducing the physical wear of industrial equipment to 15 $20 \%$ (today - 50-55\%). Along with this, the driving force behind neo-industrialization, which originates in the system of capital reproduction relations, is the change in its production structure - the growth of intellectual capital share in the process of investing in the digitalization of industry and the release of microprocessor equipment (against the background of a reduction in investment in energy production and electricity production, industrialization of the 20th century). There are also new sources of capital reproduction for example, the use of emission quotas as a source of financing for the development and introduction of new technologies (from the experience of China). An equally important driving force for neo-industrialization is the change in the nature of labor, which consists in its intellectualization, as well as in the combination of labor between workers and electronic devices.

The cluster conditions of neo-industrialization consist in changing the structure of the process of allocating productive forces, which is gradually moving away from the principle of proximity to natural resources and processing centers, and takes a networked decentralized form. The formation of network innovation clusters is determined not by the principle of providing resources, but by the effectiveness of state support for entrepreneurship in the innovation sphere, scientific and technological policy. The development process of agglomerates of the newest technologies relies not only on the available resource base, but also on the innovative potential of scientific organizations and technological platforms, technologies formed in the military-industrial complex. This implies the unification of enterprises into a single diversified production cycle of science- 
intensive products, their competitive resource support, and the development of science in corporations.

First of all, the purposeful formation of a favorable environment for the development of economic relations in the reproduction sphere, labor market, capital, resources, and information refers to the market conditions of neo-industrialization. Such an environment should not replace the market, but contain much less entropy than it has. In the Russian economy, this means overcoming the destructive function of the established primitive, "grunder" market, which has demonstrated its fiasco from the very beginning of reforms. Neo-industrially oriented economic transformations affect both market relations and property relations, and imply the inevitable transformation of private and public property in the sectors most sensitive to scientific and technological progress into public-private partnerships. In the framework of the latter, the entropy of the market is reduced and, nevertheless, market principles of competition and economic efficiency remain, so hightech industries are now becoming leaders in investment attractiveness in developed countries.

Realization of market conditions for neo-industrially oriented reforms can take various forms, such as lobbying the interests of high-tech firms in the domestic and foreign markets, state support for private investments in $\mathrm{R} \& \mathrm{D}$, promotion of innovations in mass production through public-private partnerships, state guarantees and state loans, subsidy assistance for interest rates and tax incentives for import substitution, regulation of interaction between innovative firms and natural monopolies.

The social conditions of neo-industrialization consist in the purposeful formation of stable social groups that determine the depth of penetration of the most modern technologies into industrial production and the development of high-tech services. The acceleration of scientific and technological progress modifies the economic relations of the labor market connected with the hiring of workers, which gradually acquires a network form, changes the nature of labor, making it more creative and informative. Consequently, neo-industrial social groups can be formed, on the one hand, in the process of labor interrelations development, on the other hand, in the course of innovative development of industry and services, changes in the requirements for the quality of labor stipulated by the diffusion of innovations. In turn, in order to ensure that these neo-industrial social groups are stable, the transformation of the state employment policy, stimulating the growth of employees' incomes depending on the intellectualization of labor, is required.

To the technological conditions of neo-industrialization we refer:

- modernization of the basic branches of the economy - the formation of post-oil energy (super-powerful solar batteries, bio-generators, etc.), superconductivity, recycling and energy technologies, etc.;

- innovative development of the 4th and 5th technological layers - expansion of air transportation, increase of energy efficiency of industry (transformation of energy deficit from negative into a positive factor of its development);

- development of high-tech productions and services of a new type - information networks of "cloud computing" and supercomputers, biochemical, radio-electronic, nano-material technologies.

\section{Conclusion}

We believe that the technological conditions of neo-industrially oriented economic transformations can be realized only in conjunction with reproductive, institutional and cluster conditions. The technological basis that is being formed today in the developed countries is mediated by the transformation of economic relations of property, the capital and labor market. The change in ownership structure in the most dynamically 
technologically developing sectors of the modern economy is caused by the development of public-private investment in the creation of innovations and their commercialization. The hiring relationship is gradually transformed into the cooperation of independent workers self-employed, freelancers - with innovative companies, based on the transfer of the intellectual product - the result of their labor.

The most specific forms of modification of investment, labor relations in the process of realizing the technological conditions of the neo-industrial transformations of the economy are the development of technological platforms, public-private partnerships and innovative clusters.

\section{References}

1. J. Janočko, M. Cehlár, Z. Šimková, Economics and Innovation Management, 3, 32-45 (2017) DOI: 10.26730/2587-5574-2017-3-32-45

2. Z. Šimková, M. Cehlár, H. Pavolová, Acta Montanistica Slovaca, 21:3, 208-216 (2016)

3. E. E. Zhernov Economics and Innovation Management, 2, 11-23 (2017) DOI: 10.26730/2587-5574-2017-2-11-23

4. M. Tyulenev, Y. Lesin, E. Tyuleneva, E. Murko, E3S Web of Conferences, 15, 02003 (2017)

5. M. Cehlár, J. Janočko, Z. Šimková, T. Pavlik, E3S Web of Conferences, 15, 01019 (2017)

6. M. Cehlár, L. Mihok, Theoretical and Empirical Researches in Urban Management, 8:4, 60-72 (2013)

7. M., Prokudina, O. Zhironkina, O. Kalinina, M. Gasanov, F. Agafonov, E3S Web of Conferences, 21, 04003 (2017) 